\title{
Localization of $17 \beta$-hydroxysteroid dehydrogenase type 1 mRNA in mouse tissues
}

\author{
G Pelletier, V Luu-The, S Li, L Ren and F Labrie \\ Oncology and Molecular Endocrinology Research Center, Centre de Recherche du Centre Hospitalier de l'Université Laval (CRCHUL), 2705, \\ Laurier Boulevard, Québec, Québec GIV 4G2, Canada \\ (Requests for offprints should be addressed to Georges Pelletier; Email: georges.pelletier@crchul.ulaval.ca)
}

\begin{abstract}
The enzyme $17 \beta$-hydroxysteroid dehydrogenase (17 $\beta$-HSD) type 1 catalyzes the conversion of estrone $\left(E_{1}\right)$ into $17 \beta$ estradiol $\left(E_{2}\right)$. To gain information about the cellular localization of $17 \beta$-HSD mRNA type 1 expression, we performed in situ hybridization using a ${ }^{35} \mathrm{~S}$-labeled cRNA probe in several tissues of adult mice of both sexes. In the ovary, high expression was found in granulosa cells of growing follicles. No specific labeling could be observed in corpora lutea or interstitial cells. In the pituitary gland of animals of both sexes, $17 \beta$-HSD type 1 mRNA was expressed in the intermediate lobe melanotrophs while no specific signal could be detected in the anterior or posterior lobes of the pituitary. In the prostate, $17 \beta$-HSD type 1 mRNA was exclusively found in the epithelial cells. In both male and female mouse dorsal skin, a specific hybridization signal was seen in the sebaceous glands while the epidermis, stroma, hair follicles and sweat glands were unlabeled. In the testis, a hybridization signal was detected in germ cells of the seminiferous tubules, Leydig cells being unlabeled. The present data indicate that $E_{2}$ can be formed through the action of $17 \beta$-HSD type 1 in specific cells of the gonads and peripheral tissues. In the testes and peripheral tissues, the action of $E_{2}$ is probably limited to the cells involved in its formation in an intracrine fashion.
\end{abstract}

Journal of Molecular Endocrinology (2004) 33, 459-465

\section{Introduction}

The 17 -hydroxysteroid dehydrogenase (17 $\beta$ HSD) enzymes play essential roles in steroid hormone formation by catalyzing the final steps in androgen and estrogen biosynthesis (Labrie et al. 2000, 2003, Luu-The 2001, Mindnich et al. 2004). The molecular structure of human $17 \beta$-HSD type 1 cDNA and of its corresponding gene which encodes a predicted protein of 327 amino acids was the first to be elucidated (Peltoketo et al. 1988, Luu-The et al. 1989). This enzyme, a member of the short-chain alcohol dehydrogenase superfamily, is a cytosolic protein that exists in a homodimeric form, that predominantly catalyzes the interconversion of estrone $\left(\mathrm{E}_{1}\right)$ to estradiol $\left(\mathrm{E}_{2}\right)$ using $\operatorname{NADP}(\mathrm{H})$ as a cofactor (Dumont et al. 1992, Lin et al. 1992). An analysis of the tissue distribution revealed the expression of $17 \beta$-HSD type $1 \mathrm{mRNA}$ in steroidogenic as well as various other peripheral tissues, including the placenta, ovary, breast, endometrium, prostate, skin and adipose tissue (Peltoketo et al. 1988, Dumont et al. 1992).

A mouse $17 \beta$-HSD type 1 cDNA has also been cloned and found to encode a protein of 344 amino acid residues (Nokelainen et al. 1996, Mustonen et al. 1997). The mouse enzyme shows $63 \%$ overall identity with that of the human. The mouse $17 \beta$-HSD type 1 mRNA transcript was found in ovarian granulosa cells, but not in term placenta (Nokelainen et al. 1996). Transient expression studies of mouse recombinant $17 \beta-\mathrm{HSD}$ type 1 have shown that the enzyme efficiently converts $\mathrm{E}_{1}$ to $\mathrm{E}_{2}$ and also androstenedione to testosterone (Nokelainen et al. 1996, Mustonen et al. 1997).

The localization of $17 \beta$-HSD type 1 mRNA at the cellular level has not been reported so far. We therefore used in situ hybridization (ISH) to localize the $17 \beta$ mRNA type 1 in several tissues in adult mice of both sexes to gain information about the exact sites of expression of the enzyme. 


\section{Materials and Methods}

\section{Animals}

Four adult male (26-30 g) and female (24-27 g) C57BL6 mice were housed under constant temperature $\left(21 \pm 1{ }^{\circ} \mathrm{C}\right)$ and light (lights on from 0600 to $2000 \mathrm{~h}$ ) regimen. The animals received Purina Chow (Ralston-Purina, St-Louis, MO, USA) and tap water ad libitum. The experiment was conducted in an animal facility approved by the Canadian Council on Animal Care (CGAC) and by the Association for Assessment and Accreditation of Laboratory Animal Care (AAALAG). The study was performed in accordance with the CCAC Guide for Care and Use of Experimental Animals. The animals were all perfused between 0900 and $1000 \mathrm{~h}$ for histological procedures as described below. The females were on diestrous day 1 .

\section{Histological procedures}

All the animals were deeply anesthetized with an i.m. injection of ketamine hydrochloride $(80 \mathrm{mg} / \mathrm{kg}$ body weight (bw); Bayer Inc. Toronto, Canada) and zylazine $(10 \mathrm{mg} / \mathrm{kg} \mathrm{bw})$. They were perfused transcardially with $50 \mathrm{ml} \mathrm{4 \%}$ (w/v) paraformalde-

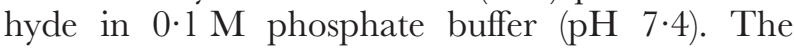
different tissues, i.e., liver, kidney, lung, skin, adrenal, pituitary, testis, prostate, ovary, uterus, vagina, mammary gland and brain were excised and postfixed in the same fixative for $24 \mathrm{~h}$ at $4{ }^{\circ} \mathrm{C}$. The tissues were placed in $15 \%$ sucrose in $0.1 \mathrm{M}$ phosphate buffer before being quickly frozen in isopentane cooled in liquid nitrogen.

\section{ISH}

Frozen sections $(10 \mu \mathrm{m}$ thick) were serially cut at $20{ }^{\circ} \mathrm{C}$ and mounted on gelatin- and poly-L-lysinecoated slides. The vector used for the production of the cRNA probe was constructed by the insertion of a cDNA fragment (504 bp) of mouse 17 $\beta$-HSD type 1 (GeneBank accession number NM_010475) into a pBSKSII+ vector (Statagene, La Jolla, CA, USA). The cDNA fragment located at position 47-550 downstream from the ATG start codon was obtained by amplification using PCR. ISH with the antisense and sense ${ }^{35} \mathrm{~S}$-labeled cRNA probes was performed as previously described (Givalois et al. 1997). Following hybridization procedures, the sections were then dehydrated and exposed onto
Kodak Biomax MR films for 3-8 days before being coated with liquid photographic emulsion (KodakNTB2; diluted 1:1 with water). Slides were exposed for 3-45 days, developed in Dektol developer (Kodak, Rochester, NY, USA) for $2 \mathrm{~min}$, and fixed in rapid fixer (Kodak) for 4 min. Thereafter, the sections were rinsed and coverslipped with Permount (Fisher Scientific, Montreal, Canada).

\section{Results}

After 3 to 8 days of exposure of the films, specific radiolabeling was observed in the ovary, testis, prostate, pituitary gland and skin. No specific hybridization signal could be detected in the mammary gland, uterus, vagina, adrenal gland, kidney, liver, brain or lung. Identification of the cell types expressing $17 \beta$-HSD type $1 \mathrm{mRNA}$ in the different tissues was achieved following examination of photographic emulsion-coated sections. In the ovary, high labeling was only observed over the granulosa cells in growing follicles at all stages of development (Fig. 1). On the other hand, no specific labeling could be detected in primordial and primary follicles nor in corpora lutea and interstitial cells. In the testis, a specific hybridization signal was seen over seminiferous tubules, Leydig cells being devoid of any specific labeling (Fig. 2). Since we used frozen sections, a procedure which does not totally preserve the integrity of the tissues, it was not possible to identify all the cell types expressing type I 17 $\beta$-HSD mRNA in the tubules. However, it clearly appears that labeling was present over the basal region of the tubules that contain spermatogonia, spermatocytes and round spermatids.

In the pituitary gland of animals of both sexes, the hybridization signal was detected in the cells of the intermediate lobe, the anterior and posterior lobes exhibiting no specific labeling (Fig. 3). In the intermediate lobe, all the cells exhibited labeling. Since the vast majority of intermediate lobe cells are melanotrophs (Tong \& Pelletier 1992), it can be concluded that melanotrophs are expressing the enzyme. On the other hand, it cannot be totally excluded that labeling occasionally observed in the interstices between melanotrophs could be associated with folliculo-stellate cells which are few in number (Tong \& Pelletier 1992). In the prostate, specific labeling was only detected over the epithelial cells bordering the acinar lumen (Fig. 4). 

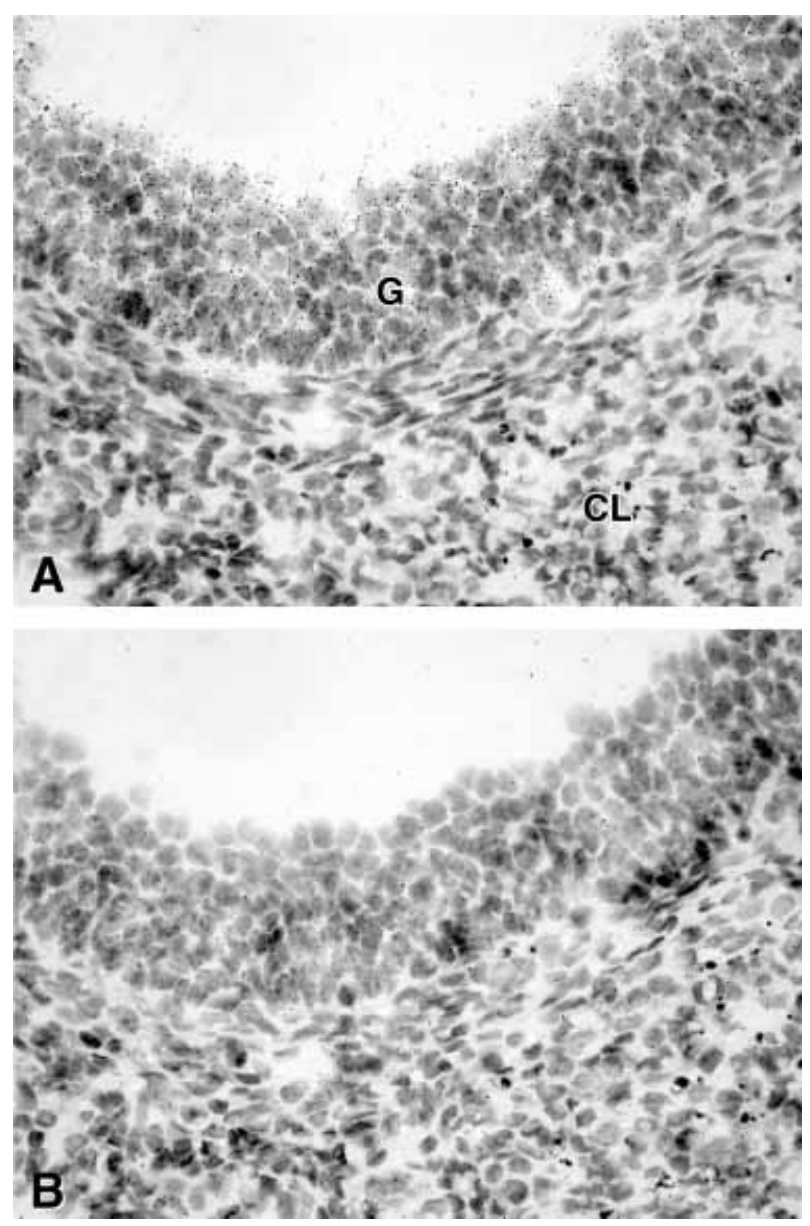

Figure 1 (A) Section through an ovary. After hybridization with the antisense probe, strong labeling is detected over granulosa cells $(G)$ of a large follicle. An adjacent corpus luteum $(\mathrm{CL})$ is unlabeled.

(B) Consecutive section hybridized with the sense probe, only weak diffuse background can be seen. Exposure time: 3 days. Magnification: $\times 600$.

On the other hand, in both male and female mouse dorsal skin, a specific hybridization signal was seen in the sebaceous glands, while the epidermis, stroma, hair follicles and sweat glands were unlabeled (Fig. 5). In all the tissues examined, hybridization with the radiolabeled sense probe generated only a light uniform labeling (Figs. 1B, 2B, 3B, 4B, 5B).

\section{Discussion}

The enzyme $17 \beta$-HSD type 1 plays an important role in the formation of $\mathrm{E}_{2}$ in the human ovary and
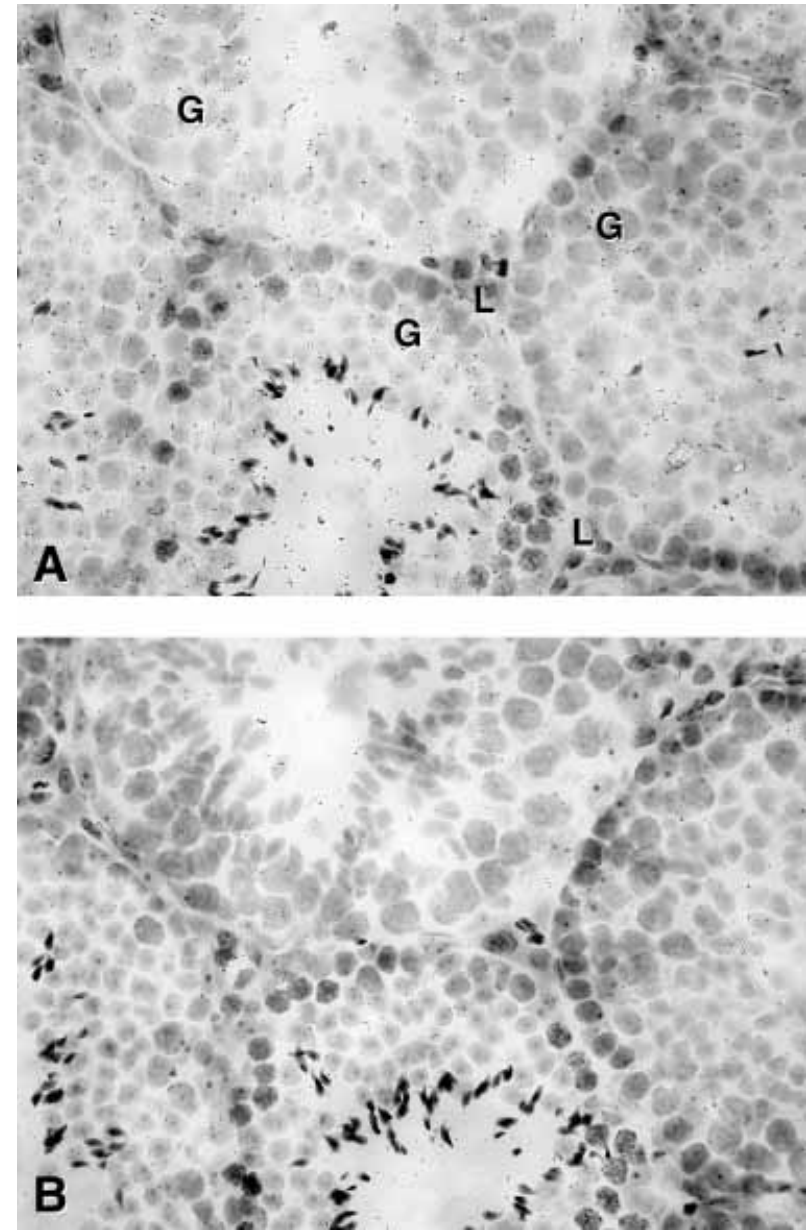

Figure 2 (A) Micrograph illustrating the hybridization signal obtained in the testis. Specific labeling is detected over germ cells $(G)$. The Leydig cells $(L)$ are unlabeled. (B) In control consecutive section hybridized with the sense probe, only diffuse background is present. Exposure time: 21 days. Magnification: $\times 600$.

placenta (Peltoketo et al. 1988, Luu-The et al. 1989, Dumont et al. 1992, Lin et al. 1992, Mustonen et al. 1997, Luu-The 2001). The recent cloning of the cDNA encoding mouse $17 \beta$-HSD type 1 has allowed studies on the histological localization of the corresponding mRNA in a series of male and female mouse tissues. In the ovary, $17 \beta$-HSD type 1 was found to be highly expressed in granulosa cells of growing follicles without any detectable hybridization signal in the corpora lutea and interstitial cells. These results agree with previous reports indicating the presence of $17 \beta$-HSD type 1 mRNA transcripts in the human, rat and mouse granulosa cells (Nokelainen et al. 1996, Akinola et al. 

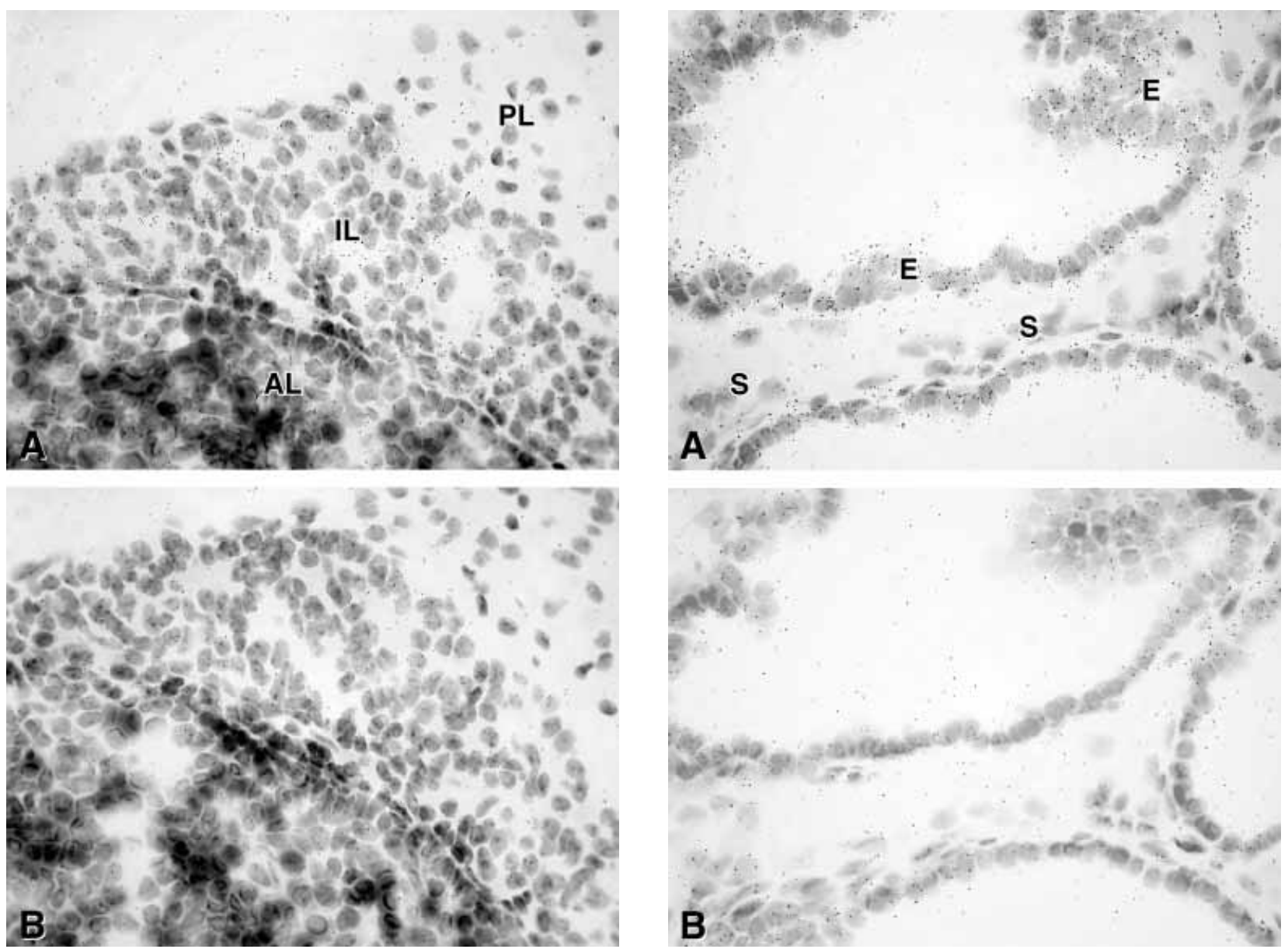

Figure 3 (A) Section through the pituitary gland of a male mouse. Accumulation of silver grains are seen over cells of the intermediate lobe (IL). The anterior (AL) and posterior $(\mathrm{PL})$ lobes do not exhibit any specific labeling. (B) Control sections hybridized with the sense probe. Only diffuse background can be observed. Exposure time: 28 days. Magnification: $\times 600$.

1997, Mustonen et al. 1997, Luu-The 2001). Using microdissection procedures, Zhang et al. (1996) have reported the expression of $17 \beta$-HSD type $1 \mathrm{mRNA}$ in human corpora lutea. This discrepancy between results obtained in rodent and human ovaries might be due to species differences or contamination of corpora lutea specimens with granulosa cells during the dissection procedure. By immunocytochemistry, it has been shown that in the human ovary, the $17 \beta$-HSD type 1 protein was only expressed in granulosa cells (Sawetawan et al. 1994). These results clearly suggest that $17 \beta$-HSD type 1 is involved in the formation of ovarian $\mathrm{E}_{2}$ which is eventually released into the general circulation. Female mice at

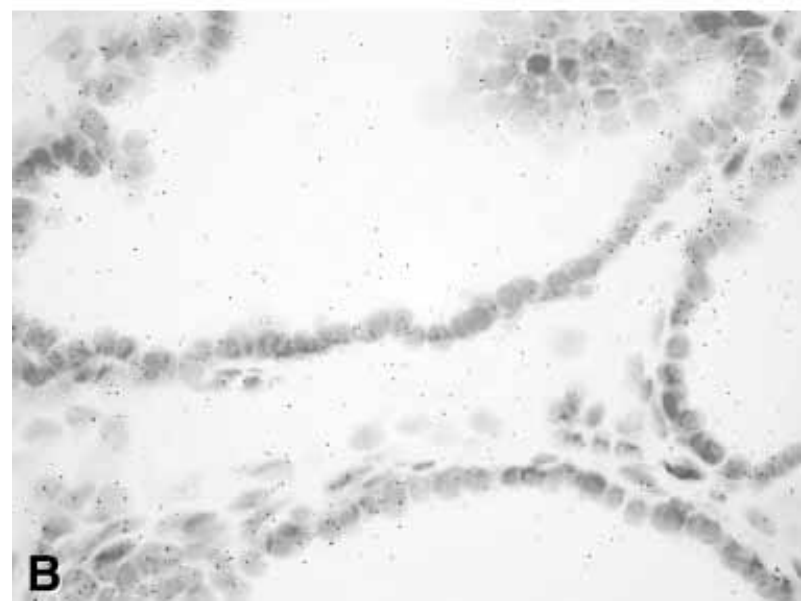

Figure 4 (A) Section through the prostate. Silver grains are found over the epithelial cells $(E)$ bordering the acinar lumen. The stroma cells (S) are unlabeled. (B). Adjacent section hybridized with the sense probe. Few dispersed silver grains can be seen. Exposure time: 28 days. Magnification: $\times 600$.

diestrous day 1 were used since at this stage of the estrous cycle, the estrogen levels are low and quite stable. It cannot be excluded that the variation in circulating levels of estrogens occurring during the estrous cycle might modulate $17 \beta$-HSD type 1 mRNA expression. We have recently observed that ovariectomy and estrogen administration to ovariectomized mice did not modify $17 \beta$-HSD type 1 mRNA levels in the skin (G Pelletier, V Luu-The, S Li, L Ren and F Labrie unpublished data), suggesting that circulating estrogens do not influence $17 \beta$-HSD type 1 expression at least in the skin.

In the testis, $17 \beta$-HSD type 1 mRNA was expressed in germ cells, especially spermatogonia, 


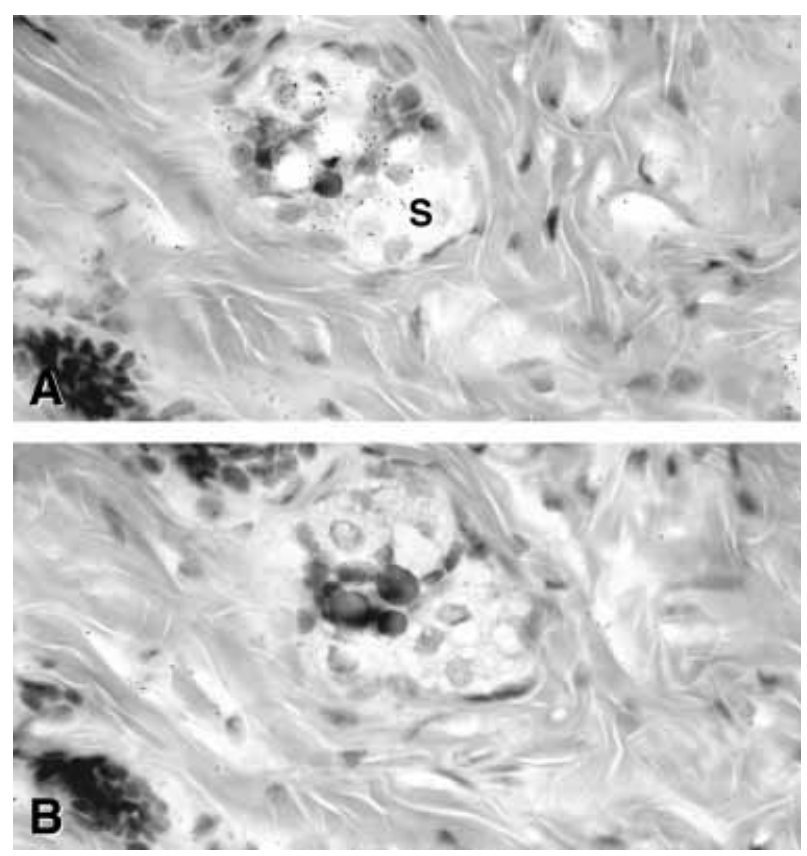

Figure 5 (A) Section through the dorsal skin of a female mouse. Specific labeling is detected over a sebaceous gland (S). (B) In control adjacent section hybridized with the sense probe, only few dispersed silver grains are present. Exposure time: 35 days. Magnification: $\times 600$.

spermatocytes and round spermatids, but not in Leydig cells, thus suggesting that the enzyme may contribute to the local production of $\mathrm{E}_{2}$ in the germinal epithelium. A low level of $17 \beta$-HSD type 1 has been detected by RT-PCR in the human testis (Nokelainen et al. 1996), but the cell type(s) expressing the enzyme have not been identified so far. The present findings, however, agree with previous studies indicating that estrogens are synthesized by germ cells (de Jong et al. 1974, Nitta et al. 1993, Kivan et al. 1995), although the role of estrogens in germ cell functions and/or development is not fully understood. On the other hand, estrogen receptors $\alpha$ have been localized in rat germ cells (Pelletier et al. 2000), thus suggesting that $\mathrm{E}_{2}$ can exert intracrine and/or paracrine activity in the seminiferous tubules.

In the brain, including the posterior lobe of the pituitary gland, which is an extension of the medio-basal hypothalamus, no specific hybridization signal could be found. In fact, only the intermediate lobe which contains a homogenous population of cells (melanocytes) with very few folliculo-stellate cells (Tong \& Pelletier 1992) exhibited expression of $17 \beta$-HSD type 1 mRNA.
Since the labeling was rather uniform, it can be concluded that the vast majority of the melanocytes, if not all of them, express the enzyme and are thus involved in $\mathrm{E}_{2}$ formation. In the rat intermediate lobe, Shugrue et al. (1998) reported that ER $\beta$ mRNA but not ER $\alpha$ was expressed. On the other hand, Mitchner et al. (1998) found that both $\mathrm{ER} \alpha$ and $\mathrm{ER} \beta \mathrm{mRNAs}$ were expressed in the rat intermediate lobe, with a higher expression of $\mathrm{ER} \alpha$ mRNA. By immunocytochemistry, neither $\mathrm{ER} \alpha$ nor $\operatorname{ER} \beta$ protein could be detected in the rat intermediate lobe of the pituitary (Pelletier et al. 2000). It remains to be determined whether or not locally produced $\mathrm{E}_{2}$ can exert an intracrine activity in mouse intermediate lobe melanotrophs. The role of estrogens on melanotroph functions is still unclear. In fact, under in vivo conditions, estrogen treatment could induce an increase in the release of $\alpha$-melanocyte stimulating hormone (Ellerkman \& Nagy 1992), but there is no evidence that estrogen can directly modulate melanotrophs.

In the prostate, $17 \beta$-HSD type 1 mRNA was exclusively detected in the epithelial cells bordering the acinar lumen (luminal cells). In the mouse prostatic acini, the majority of epithelial cells are luminal cells, while the basal cells are rather scarce. In fact, the ratio of luminal to basal cells is approximately 10:1 (El-Alfy et al. 2000). It can thus be logically assumed that most of the specific labeling is originating from the luminal cells. The presence of $17 \beta$-HSD type 1 has been reported in the human prostate (Luu-The et al. 1990, Dumont et al. 1992), but identification of prostate cell types expressing the enzyme have not been reported. Since $\operatorname{ER} \beta$ has also been reported in luminal cells in the prostate of several species, including the mouse (Couse \& Korach 1999, Pelletier 2000, Pelletier et al. 2000), it can be suggested that $\mathrm{E}_{2}$ synthesized in luminal cells through the action of $17 \beta$-HSD type 1 might exert an intracrine activity. The physiological role of estrogens in the prostate is still unclear. In $\operatorname{ER} \alpha$ or $\operatorname{ER} \beta$ knockout mice, no abnormality of the development of the prostate has been found (Couse et al. 2000, Dupont et al. 2000). On the other hand, we have reported that $\mathrm{E}_{2}$ administrated to castrated rats could induce moderate hypertrophy of prostate epithelial cells as well as an increase in androgen receptor expression in epithelial and stromal cells (Pelletier 2002).

In the dorsal skin of mice of both sexes, $17 \beta$ mRNA type 1 was only detected in sebocytes. 
Sebocytes have been shown to express both ER $\alpha$ and ER $\beta$ with a much higher expression of ER $\beta$ (Pelletier 2000, Thornton et al. 2003). It thus appears that locally produced estrogens can likely be involved in the regulation of sebaceous gland activity. Recent studies using sebaceous glands in culture have shown that physiological levels of estradiol significantly decreased lipogenesis without affecting the rate of cell division (Guy et al. 1996). The mechanisms involved in the regulation of the local production of estrogens in the skin remain to be elucidated.

By RT-PCR analyses, Nokelainen et al. (1996) have detected very low levels of $17 \beta$-HSD type 1 mRNA in the uterus and adrenal glands of female mice. In the present study, we have been unable to detect any hybridization signal in the uterus or adrenal glands. This discrepancy between the two approaches can simply be explained by a lower sensitivity of the ISH technique.

In summary, we report for the first time the identification of cell types expressing $17 \beta$-HSD type $1 \mathrm{mRNA}$ in mouse gonads and peripheral tissues. In the testis and peripheral tissues, the action of $\mathrm{E}_{2}$ formed through $17 \beta$-HSD type 1 is probably limited to the cells involved in the formation of $\mathrm{E}_{2}$ in an intracrine fashion (Labrie 1991). It is noteworthy that tissues expressing $17 \beta$-HSD type 1 are also expressing aromatase (Sharpe 1998, Simpson et al. 2000), thus suggesting that $\mathrm{E}_{2}$ is produced by aromatization of 4-androstenedione (4-dione) into $\mathrm{E}_{1}$ followed by the conversion of $\mathrm{E}_{1}$ into $\mathrm{E}_{2}$ by $17 \beta$-HSD type 1 , rather than by aromatization of testosterone into $\mathrm{E}_{2}$.

\section{Acknowledgements}

ATLAS program supported by Genome Canada and Genome Quebec.

\section{References}

Akinola LA, Poutanen M, Vihko R \& Vihko P 1997 Expression of 17 beta-hydroxysteroid dehydrogenase type 1 and type 2, P450 aromatase, and 20 alpha-hydroxysteroid dehydrogenase enzymes in immature, mature, and pregnant rats. Endocrinology 138 2886-2892.

Couse JF \& Korach KS 1999 Estrogen receptor null mice: what have we learned and where will they lead us? Endocrine Reviews 20 358-417.

Couse JF, Curtis Hewitt S \& Korach KS 2000 Receptor null mice reveal contrasting roles for estrogen receptor alpha and beta in reproductive tissues. Fournal of Steroid Biochemistry and Molecular Biology 74 287-296.

Dumont M, Luu-The V, de Launoit Y \& Labrie Y 1992 Expression of human $17 \beta$-hydroxysteroid dehydrogenase in mammalian cells. Journal of Steroid Biochemistry and Molecular Biology 41 605-608.

Dupont S, Drust A, Gansmuller A, Dierich A, Chambon P \& Mark M 2000 Effect of single and compound knockouts of estrogen receptors alpha (ERalpha) and beta (ERbeta) on mouse reproductive phenotypes. Development 127 4277-4291.

El-Alfy M, Pelletier G, Hermo LS \& Labrie F 2000 Unique features of the basal cells of human prostate epithelium. Microscopy Research and Technique $\mathbf{5 1} 436-446$.

Ellerkman E \& Nagy G 1992 Alpha-melanocyte stimulating hormone is a mammotrophic factor released by neurointermediate cells after estrogen treatment. Endocrinology 130 133-138.

Givalois L, Li S \& Pelletier G 1997 Age-related decrease in the hypothalamic CRH mRNA expression is reduced by dehydroepiandrosterone (DHEA) treatment in male and female rats. Brain Research. Molecular Brain Research 48 107-114.

Guy R, Ridden C \& Kealy T 1996 The improved organ maintenance of the human sebaceous gland: modeling in vitro the effects of epidermal growth factor, androgens, estrogens, 13-cis retinoic acid, and phenol red. Fournal of Investigative Dermatology 106 $454-460$.

de Jong FH, Hey AH \& van der Molen HJ 1974 Estradiol 17 beta and testosterone in rat tissue: effect of gonadotrophins, localization and production in vitro. Fournal of Endocrinology 60 409-419.

Kivan S, Hess RA, Bunick D, Nitta H, Janulis L, Osawa Y \& Bohr JM 1995 Rooster testicular germ cells and epididymal sperm contains P450 aromatase. Biology of Reproduction 53 1259-1264.

Labrie F 1991 Intracrinology. Molecular and Cellular Endocrinology 78 C113-C118.

Labrie F, Luu-The V, Lin S-X, Simard J \& Labrie C 2000 Role of $17 \beta$-hydroxysteroid dehydrogenases in sex steroid formation in peripheral intracrine tissues. Trends in Endocrinology and Metabolism $11421-427$.

Labrie F, Luu-The V, Labrie C, Belanger A, Simard J, Lin SX \& Pelletier G 2003 Endocrine and intracrine sources of androgens in women: inhibition of breast cancer and other roles of androgens and their precursor dehydroepiandrosterone. Endocrine $\mathbf{2 4}$ 152-182.

Lin SX, Yang F, Jin JZ, Breton R, Zhu DW \& Luu-The V 1992 Subunit identity of the dimeric 17 beta-hydroxysteroid dehydrogenase from human placenta. Fournal of Biological Chemistry 267 16182-16187

Luu-The V 2001 Analysis and characteristics of multiple types of human 17 beta-hydroxysteroid dehydrogenase. Fournal of Steroid Biochemistry and Molecular Biology 76 143-151.

Luu-The V, Labrie C, Zhao HF, Couet J, Lachance Y, Simard J, Leblanc G, Côté J, Bérubé G, Gagné R et al. 1989 Characterization of cDNAs for human estradiol 17 $\beta$-HSD and assignment of the gene to chromosome 17: evidence of two mRNA species with distinct $5^{\prime}$ termini in human placenta. Molecular Endocrinology 3 1301-1309.

Luu-The V, Labrie C, Zhao HF, Couet J, Lachance Y, Simard J, Leblanc G, Côté J, Bérubé D, Gagné R et al. 1990 Purification, cloning, complementary DNA structure and predicted amino acid sequence of human estradiol 17ß-dehydrogenase. Annals of the New York Academy of Sciences $\mathbf{5 9 5}$ 40-52.

Mindnich R, Müller G \& Adamski J 2004 The role of 17 beta-hydroxysteroid dehydrogenases. Molecular and Cellular Endocrinology 218 7-20.

Mitchner NA, Garlick C \& Ben-Jonathan N 1998 Cellular distribution and gene regulation of estrogen receptors $\alpha$ and $\beta$ in the rat pituitary gland. Endocrinology 139 3976-3983.

Mustonen MVJ, Poutanen MH, Isomaa W \& Vihko RK 1997 Cloning of mouse 17b-hydroxysteroid dehydrogenase, type 2, 
and analysing expression of the mRNA for types 1, 2, 3, 4 and 5 in mouse embryos and adult tissues. Biochemical fournal 325 199-205.

Nitta H, Bunick D, Hess RA, Janulis L, Newton SC, Millette CF, Osawa Y, Shizuta Y, Toda K \& Bahr JM 1993 Germ cells of the mouse testis express P450 Aromatase. Endocrinology 132 1396-1401.

Nokelainen P, Puranen T, Peltoketo H, Orava M, Vihko PT \& Vihko RK 1996 Molecular cloning of mouse 17 beta-hydroxysteroid dehydrogenase type 1 and characterization of enzyme activity. European Fournal of Biochemistry $236482-490$.

Pelletier G 2000 Localization of androgen and estrogen receptors in rat and primate tissues. Histology and Histopathology $\mathbf{1 5}$ 1261-1270.

Pelletier G 2002 Effects of estradiol on prostate epithelial cells in the castrated rat. Fournal of Histochemistry and Cytochemistry $\mathbf{5 0}$ 1517-1523.

Pelletier G, Labrie C \& Labrie F 2000 Localization of oestrogen receptor $\alpha$, oestrogen receptor $\beta$ and androgen receptors in the rat reproductive organs. Fournal of Endocrinology $\mathbf{1 6 5}$ 359-370.

Peltoketo H, Isomaa V, Maentausta O \& Vihko R 1988 Complete amino acid sequence of human placental $17 \beta$-hydroxysteroid dehydrogenase deduced from cDNA. FEBS Letters 239 73-77.

Sawetawan C, Milewich L \& Word RA 1994 Compartimentalization of type 117 beta-hydroxysteroid oxidoreductase in the human ovary. Molecular and Cellular Endocrinology $99604-610$.
Sharpe RM 1998 The roles of oestrogen in the male. Trends in Endocrinology and Metabolism 9 371-378.

Shugrue PJ, Lane MV, Scrimo PJ \& Merchenthaler I 1998 Comparative distribution of estrogen receptor-alpha (ER-alpha) and beta (ER-beta) mRNA in the rat pituitary, gonad, and reproductive tract. Steroids $\mathbf{6 3} 498-504$.

Simpson E, Rubin G, Clyne C, Robertson K, O'Donnell L, Jones M \& Davis S 2000 The role of local estrogen biosynthesis in males and females. Trends in Endocrinology and Metabolism 11 184-188.

Thornton MJ, Taylor AH \& Mulligan K 2003 Oestrogen receptor beta is the predominant estrogen receptor in human scalp skin. Experimental Dermatology 12 181-190.

Tong Y \& Pelletier G 1992 Role of dopamine in the regulation of proopiomelanocortin (POMC) mRNA levels in the arcuate nucleus and pituitary gland of the female rat as studied by in situ hybridization. Brain Research. Molecular Brain Research 15 27-32.

Zhang Y, Word RA, Fesmire S, Carr BR \& Rainey WE 1996 Human ovarian expression of 17 beta-hydroxysteroid dehydrogenase types 1,2 and 3. Fournal of Clinical Endocrinology and Metabolism 81 3594-3598.

Received 2 April 2004

Accepted 11 June 2004

Made available online as an

Accepted Preprint 23 June 2004 